\title{
A Literature Review On The Development Phases Of Hungarian Pig Industry (1990-2003) Part II
}

\author{
Vinkler Belane, PhD student \\ Budapest Metropolitan University, Heller Farkas Faculty of Tourism and \\ Economy, Institute of Economics, Hungary \\ Beatrix Lenkovics, PhD student \\ Budapest University of Economy, Department of Hospitality \\ Csilla Kalmar-Rimoczi, PhD student \\ Pallasz Athéné University, University Faculty of Szolnok, \\ Department of Tourism and Catering, Hungary
}

doi: 10.19044/esj.2016.v12n23p412 URL:http://dx.doi.org/10.19044/esj.2016.v12n23p412

\begin{abstract}
In the course of our socio-economic development regional issues get disparate emphasis in differing time cross-sectional views. There are periods when they are discarded from the centre of attention, while other times come to the forefront and Hungary devote special attention to the changes in regional differentiation, the inequalities in development levels, and the formation of structural diversity. This fluctuation of interest is connected to the constant changes in global, regional and local trends, the internal and external factors and processes as well as their outcomes based on their subtle interdependence. While in our world of globalisation markets are global, company strategies are global, innovations also spread globally, lasting competitive advantages remain local. This paradox of global versus local also underlines the importance of regional analyses (Abonyi \& Vinkler, 2012).

Part II follows the period before Hungary’s accession to the European Union, highlighting all the events and changes that resulted in the profound transition of the country's economy impacting also our foreign markets. This period stretches from 1990 to 2003.
\end{abstract}

Keywords: Political-economic transition, farmers, pig industry, competitiveness, the EU 


\section{The period preceding accession to the European Union (1990-2003)}

The political-economic transition found the country and the whole society in a state of unpreparedness. Land privatisation and the introduction of compensation vouchers brought a fundamental change in land holding structure and eventually major pig farms and slaughterhouses ended up in the hands of a group of investors. One of the consequences of this process was the loss of East-European food markets. The core problem with the privatised land and animal farms was that the new owners did not dispose over the adequate conditions. The sale of lands surrounding animal farms brought a handicap in supplyin livestock with fodder and forced animal farmers to lease land to raise forage. The $60-75 \%$ of production overheads in animal farming is made up by the cost of foraging. Slowly but surely globalisation and the switch to market economy crept into the country during this transition period (Veress \& Dunka, 2003).

The stability of purchasing prices before the systemic change made planning possible and ensures a certain safety for producers bringing them a $16-17 \%$ rate of income related profitability. After 1990, profitability rates started fluctuating due to changes in purchasing and fodder prices. As a result of decreasing purchasing prices and the narrowing of market opportunities an oversupply in pork occurred causing tension and uncertainty in the sector. By the end of the 1990s, the capacity of meat processing plants fell to 5-5.5 million heads. Meat processing plants cornered $48 \%$ of slaughtered pigs, $18 \%$ was done in slaughterhouses, while households accounted for $34 \%$ of all slaughters. The drastic decline in pig farming continued throughout the decade and it occurred on a global scale (Nábrádi, Szücs, Balogh, 2000).

Sántha (1999), came to the conclusion that the disintegration and subsequent dissolution of farmers' co-operatives in the course of the 1990s also decreased the production of the integrated plants. The shrinking market position of the animal farming sector and the growing indebtedness of its actors led pig farmers to solve their liquidity problems by selling their livestock as there were no other options for them. The weight of animal farming within agricultural production value dropped significantly. The pig farming sector was unable to exploit the opportunities offered by the production of crop matrices and thereby improving the quality of their products to become competitive again on international markets. In order to improve their specific yields and produce quality products, animal farming must ensure an adequate capital supply, employ people with adequate expertise and acquire important positions by building market relationships.

The repeated attempts of small farmers to access these markets ended in failure and heavy financial loss speeding up the decrease in livestock. The 
animals raised in an extensive way and fed on home-grown fodder yielded poorer quality products which resulted in the loss of marketability. A setback in the international competitiveness of Hungarian animal farming in turn led to the loss of important export markets.

When we look at the structure of animal farming, we discover disparate changes taking place: the share of poultry farming was only $20.1 \%$ in 1960 , which grew to $28.3 \%$ by 1990 , and reached $34 \%$ in 1995 , making it a dominant sector and signalling a clear preference in the consumption of the population. At the same time, a serious decrease took place in the cattle livestock. In 1990, it numbered 1 million heads, while pig livestock fell below 5 million and poultry stock reached almost 36 million.

The development of Hungarian agriculture in the $20^{\text {th }}$ century was dominated by animal farming, it functioned as a driving force. At the beginning of the 1990s, with the decline of animal farming, crop production exceeded $50 \%$ of total production value. The number of sows held by private farmers fell by 46\% in the years between 1990 and 1993 as they were too slow to respond to market changes. By the fall of 1995, sow livestock fell to 5,572 thousand heads which meant a 40\% decrease compared to the figure of 1990. As a result the pinch of the market also affected our exports and the rising price of pork resulted in a fall of domestic consumption.

Due to adverse weather conditions and a recurring drought in the summers fodder prices increased significantly. It made a further adverse impact on pig livestock which fell back so much that the country was forced to import pork and domestic production capacities laid idle. The seasonal character of pig farming can be described by cyclical changes. The cycle begins in the fall and ends with the population's slaughters in December. Farmers tend to time the sows' kindling for the spring to avoid the cold winter months. In order to ensure profitability farmers would embark on breeding and fattening, however, when profitability decreases, they choose to reduce their livestock or even terminate it completely.

Comparing the specific yields of the Hungarian pig livestock with that of other member states of the Európean Union, there are conspicuous differences. In the EU the growth of one sow is 19-20 heads, the lean meat ratio of a slaughter pig is 55-59\%, while the specific fodder need of one $\mathrm{kg}$ mass gain is $2.9 \mathrm{~kg}$, and the average daily mass gain of fattened pigs is 750$800 \mathrm{~g} /$ day. In contrast, in Hungary the growth of one sow is 15-16 heads, the lean meat ration of a slaughter pig is $49 \%$, the specific fodder need of one $\mathrm{kg}$ mass gain is $3.88 \mathrm{~kg}$, and the daily mass gain of fattened pigs is 550600 g/day.

Examining the export situation of slaughtered pigs the volume of exported stock in 1991 stood at 326.6 thousand tons, which fell back to 72.3 thousand tons by 1995. This in turn required the increase of imports, which 
in 1990 was only 3.4 thousand tons, but increased steadily and by 1995 reached 40.4 thousand tons. The balance of exports and imports dropped to one tenth of its former volume and in 1995 stood at 31.9 thousand tons, which also shows the continuous increase of imports in these years. Another new economic factor worth noting is that, due to EU regulations, small slaughterhouses began to spring up and triggered a competition among industrial purchasers. In the process of privatization meat processing plants and slaughterhouses went to private and sometimes foreign owners. As a result of the increasing imports the exploitation of domestic capacities declined and the accumulation of fixed costs raised overhead costs, which exerted an unfavourable impact on competitiveness on international markets (Magda, 1998).

Food processing companies and big retail chains took control of the whole food chain and affected significant changes in foodstuff prices. The growth in global market prices did not follow the increase in domestic production costs. The contribution of Hungarian food industy to GDP in the period between 1990 and 1996 fluctuated between $16.9 \%$ and $10.7 \%$.

The introduction of intervention depends on the size of market disruptions; in case of pork, when the market price falls below 103\% of base price, intervention is implemented in accordance of the directions of the AGENDA 2000 (Berlin Summit, 1999). In order to hold back price increases and create stability private storage should be supported. To regulate imports, specific duties were introduced in 1995, and exports were supported and tied to licences (Varga \& Tunyoginé, 2007).

In the middle of the 1990s, the oversupply of pork led to a fall in prices on the global market of pig farming. The lowest prices were quoted in 1998, but by 2000 the over- production crisis of pork started to restore. In 2008, global production of pork reached 84.3 million tons, a $24.5 \%$ increase to 1998. Thanks to its low to foraging cost and high productivity rates, the USA was able to corner $76 \%$ of the international markets. As a result of the first Global Pork Conference held in New-Zealand on 2-3 May 2000, a “zero tax" was introduced effective from 1 July 2000 towards the markets of the EU, which helped to boost Hungarian exports (Réti \& Pénzes, 2001).

As Horn (1999) pointed out, the fall in the volume of livestock in the $20^{\text {th }}$ century history of Hungarian animal farming was of tragic proportions. It it wants to respond effectively to the rapidly changing market trends in the world, Hungarian agrarian economy also has to change to regain its competitiveness on the international markets. Animal farming needs improvements both in quality and quantity finding the options for diversification in order to ensure the supply of the country's population and continuously satisfy the emerging export needs. 
At the beginning of the $21^{\text {st }}$ century, a global competition has developed between the EU and the USA, as the USA aims to corner a larger share from global trade. Consequently, the EU member states including our country must take appropriate strategic steps. The competitiveness of the European Region will dramatically fall in the different sectors. The primary objectives of Hungarian animal farming must be the preservation of existing export markets by supplying high quality products meeting their demands. In the future, the introduction of hungaricums to new markets can also play an important role.

Further data show that the combined livestock and meat product export of Hungary in 1998 amounted to USD356 million, then in 1999 dropped to USD316 million, exceeding a 10\% fall in performance. A large part of meat export still went to the CIS countries, in spite of their risky nature, Russia and the Ukraine remained major export markets. Combined livestock and meat product import in 1998 was USD74 million, which fell to USD25 million in 1999, making up 80\% of all imports. The value of exports in these two years fluctuated between USD280-290 million (Nábrádi et al., 2000).

Kapronczai (2003) pointed out that the animal farming sectors were the biggest losers in agriculture in the past thirteen years following the political-economic transition (1990-2002). The data of the pig farming sector show a further decline in the second half of the decade, too. The dramatic drop in pig livestock created a crisis, the domestic pig farming industry fell to a "historic low".

A pronounced fluctuation could be detected in the domestic pig livestock figures. The volume index $(1990=100 \%)$ of gross production in pig farming fell to 84.4\% in 1991, then in 1997 did not even reach 52\%, and in 2002 barely exceeded $50 \%$ of the base year (1990). It reached the lowest point at the end of 1994, with only 4.4 million heads, which was $54 \%$ of the base year, but by the end of 2002, climbed back to 5 million heads accounting for $63 \%$ of the 1990 figure. In this period, due to the fundamental changes affecting the sector, livestock of sows showed a continuous decline. The lowest point was in 1994 with 335 thousand heads, which edged back to 381 thousand heads by the end of 2002 amounting to $61 \%$ of the 1990 figure.

Farmers had to face constant problems in selling their stock and the uncertainty and generally loss-making agrarian production forced many of them to terminate farming and production (Vinkler, 2005).

The changes in pig livestock are summed up in Diagram 1. 
Diagram 1: Changes in pig and sow livestock volumes 1990-2002 (thousand heads)

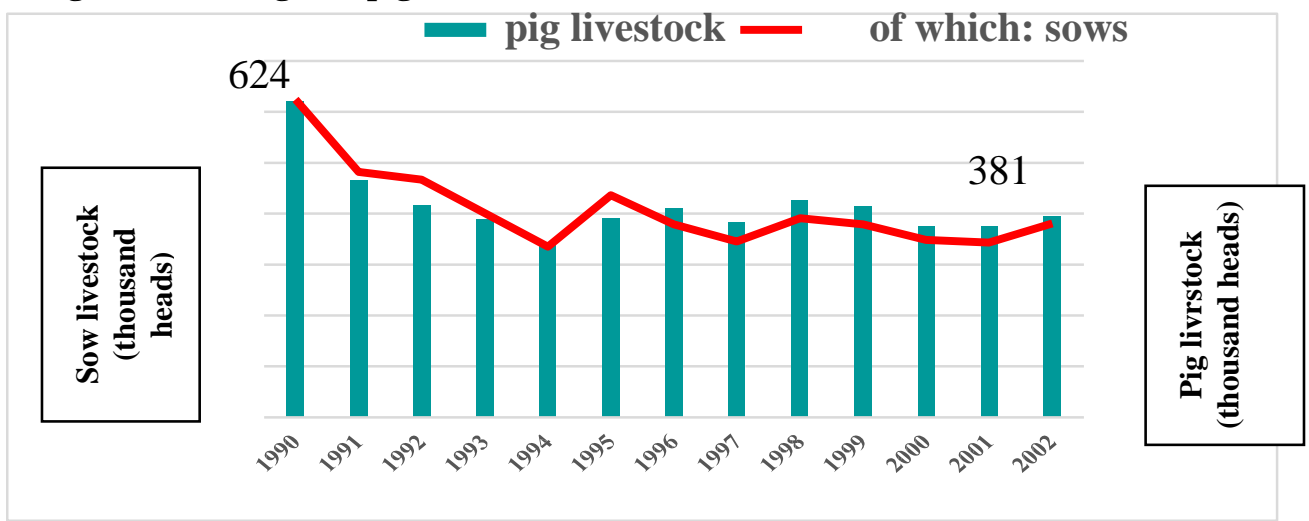

Source: Agrárkutató Intézet Információs Rendszer. Sertésinformációs rendszer Own construction

Pig farming in the EU is termed as "foul fodder-based produce" referring to its close contact with grain crops. Because of its heavy environmental impact animal farming is considered the "foul sector" of agriculture exerting a greater burden on natural elements (soil, water, air, and wildlife) of the environment. Hungarian farmers were aware of these provisions, but were unable to implement the required developments. The 1990s saw the continuous deterioration of the animal farming sector, and the attempt made at the end of 1996 to set it on a new development course failed, too (Sántha, 1999).

It is important to define the current position of pig production within the whole animal farming sector, for which it need to consider the following factors:

- an appropriate system of conditions in place (food safety, environment protection),

- breaking-out points clearly defined,

- monitoring of available subsidisation,

- accessibility of investment and development opportunities,

- financing sources available (Buzássy, 1997).

Hungarian agrarian production has gone through a restructuring process in recent years, both on the local and international markets. Quality and efficiency directives are taking greater and stronger effect. The mass production market of pork in Hungary is still dominated by products of poor quality and low production level. It would be imperative to find market niches that require meeting special consumer demand like oven ready and chilled products. The steady increase of consumer prices paired with declining living standards resulted in a drop in the population's consumption and the majority of purchases shifted to direct market sources, even to the grey economy (Sipos, 1997). 
Accession to the European Union posed a great challenge for the country. Hungary was admitted to a single market exceeding 450 million consumers with enormous demand and purchasing power where defensive duties protect the EU producers from external competitors. For the accession Hungary had to harmonise her regulations with that of the European Union. EU directives had to be applied regulating animal welfare, raising methods, management of organic manure, etc. Point 1 of Article 3 of the 91/630/EEC directive regulates the flooring space requirements. Every animal farmer who builds or renovates pigstys after 1 January 1994 has to apply these norms. Article 8 of the same directive defines the rearing conditions also stipulating that „Animals imported from non-member states have to be provided that same rearing conditions as the ones required of the member states. Artile 9 states that an expert committee has to check the observation of rearing conditions and other norms (Nábrádi \& Szücs, 2000.).

In Hungary the development and production level of livestock lagged far behind the EU specifications meeting approximately $50-60 \%$ of them. Before accession to the European Union it was necessary to implement effective measures in animal farming to develop production and meet the quality requirements of the market. Farmers had to be acquainted with the current application opportunities giving them the chance to successfully apply for European Unon funding. An important precondition for the sector's development in Hungary was to improve the economic weight and profitmaking ability of farmers (Vinkler, 2013).

In this period stretching to 2002, the government set the target of reaching 6 million heads of pigs paired with the improvement of genetic, raising and foraging technologies. At the time, $46 \%$ of pig livestock was owned by agrarian companies and co-operatives, the remaining $54 \%$ was in the hands of small farmers. This ownership structure also highlights the importance of preserving market positions and meeting quality requirements. It was also important to harmonise the main objectives of the development of animal farming with the general agrarian strategy to strengthen market positions before the EU accession.

In view of the European Union's regulations on pig farming the most delicate point in our negotiations with the $\mathbf{E U}$ was to win better opportunities for developing our production while observing the requirements of environment protection and animal welfare (size of plants, environmental impacts, technology employed). The impacts on the environment are defined partly by the standard of technology used and partly by professional knowledge and human attitude and discipline.

The political-economic transition changed the situation completely. The privatization of land and the introduction of compensation vouchers brought a fundamental change in land holding structure. Following the 
disintegration of Comecon and the collapse of Eastern markets Hungary wanted to turn our East-oriented export into West-oriented right away. The rapid changes of market and economic conditions brought by the transition and affecting almost every field of life hit the agrariansector the most heavily. Agriculture became one of he bigget losers of the transition. In the $20^{\text {th }}$ century, there had been three transition phases of great volume in Hungarian agriculture, the first one following 1945, the second after the reforms introduced in 1961, and the third following the political-economic transition. However, it was the last one that caused the largest fall in production.

Accession to the European Union was an enormous challenge for the country, but it also brought new market opportunities. The EU helped new member states with specific programs in catching up and recognizing the regulations, directives and system of requirements. EU membership, the new economic environment for agriculture brought significant changes in pork production as well. After the accession, Hungary was faced with a constantly changing environment which required constant adaptation and alignment. Following the directives and regulations also brought extra costs for the animal farming sector. Competitiveness in animal farming can only be achieved if producers pay attention to the environmental impacts of production. The pig farming sector can only develop if the actors in the vertical structure are able to exploit existing possibilities and the inherent potentials (Mucsi, 1999).

To increase competitiveness continuous innovation is necessary and is paired with substantial capital needs. If it is not available, it obliterates the advantages existing or achieved in other resources. Development sources are important not only to get to or stay in the front rank, but because of the new and peculiar situation brought about by the transition in Hungary: property ownership and land holding structures both went through fundamental changes. If alignment to the new circumstances (especially in fixed assets) does not happen, or only with a phase delay, it will may to very adverse consequences. However, the prolongued shortage of capital following the transition, unfortunately, points to this direction (Abonyi \& Vinkler, 2013).

In our age of globalization competition is getting ever fiercer, and the regions where the most modern management and organization methods are not applied, will fall behind. Some rural areas of Hungary have stranded so much behind top development "central spots" that a wider application of modern logistics methods paired with good organization and co-operation between specific spatial levels ensuring the necessary harmony, may result in very spectacular results. Our unexploited potentials are enormous (Abonyi \& Vinkler, 2012). 


\section{Conclusion}

In the field of entrepreneurship, competitiveness, research and development, innovation and job creation can not be underestimated for small and medium-sized enterprises role, the challenges face in an increasingly globalized world where many of the policies of large companies influence. New challenges in the European Union are open to small and medium-sized enterprises for participation. The enterprises must be aware of the new current tender opportunities to be realistic chance to achieve effective competition and European Union funds. The development is an important condition for hungarian small and medium entrepreneurs and improve the income generating capacity (Vinkler, 2005).

For the future, it is important to help stabilize the existing mediumsized businesses and developing thriving small businesses medium-sized company reorganization. They are subsequently directly and effectively serve the national economic policy goals. Taken together, we can say that the domestic business sector after the political changes radically changed, and the organic development of a healthy business relationship needs better suited to meaningfully improved performance (Vinkler, 2013).

\section{References:}

Abonyiné Palotás Jolán, Vinkler Béláné (2013): Az élelmiszergazdaságban rejlő tartalékok mobilizálásának néhány kérdése a Duna-térségben. III. Duna Térségi Kohézió Tanulmánykötet III. Interregionális Nemzetközi Tudományos Konferencia Dunaújvárosi Főiskola 2012.szeptember 5-6. Kiadványt Területfejlesztési Tudományos Egyesület (Gödöllő) támogatta. ISBN 978-86-85409-89-9. pp. 225-233.

Abonyiné Palotás Jolán, Vinkler Béláné (2012): Gondolatok a logisztika vidékfejlesztésben betöltött szerepének erösitéséröl, különös tekintettel a turizmusra. Logisztikai Évkönyv 2012. Magyar Logisztikai Egyesület szakmai kiadványa. ISSN 1218-3849. pp. 148-155.

Buzássy Lajos (1997): Közigazgatás, agrárgazdaság és kutatás. Glatz Ferenc szerk. A magyar agrárgazdaság jelene és kilátásai. Magyar Tudományos Akadémia, Budapest, pp 145-146.

Horn Péter (1999): Az állattenyésztésünk fejlesztésének néhány alapvetö kérdése. Állattenyésztés és Takarmányozás Vol.48 (No.6) pp 584-587.

Kapronczai István (2003): A magyar agrárgazdaság a rendszerváltástól az Európai Unióig. Szaktudás Kiadó Ház, Budapest, pp 92-94,98.

Nábrádi András, Szücs István, Balogh Péter (2000): A sertéshústermelés gazdasági kérdései. Mezőgazdasági Szaktudás Kiadó, Budapest, pp.1416,81-83.

Magda Sándor (1998): Mezőgazdasági vállalkozások szervezése és ökonómiája. Mezőgazdasági Szaktudás Kiadó, Budapest pp 461-466. 
Mucsi Imre (1999): Az állattenyésztés fejlesztésével kapcsolatos lehetöségek és feladatok az EU csatlakozás során. Állattenyésztés és Takarmányozás Vol.48 (No.6) pp. 581-584.

Réti Attila- Pénzes Éva (2001): A világ sertéshús termelésének várható alakulása. Gazdálkodás (2001.évi XLV. évfolyam 2. szám.) Agrárökonómiai Tudományos Folyóirat. pp. 43-46.

Sántha Attila (1999): Állattenyésztésünk helyzete és EU-konform fejlesztésének koncepciója. Kerekes Sándor szerk. Környezetbarát Mezőgazdálkodás. Magyar Tudományos Akadémia, Budapest. (Műhely Tanulmány) pp. 37-45.

Sipos Aladár (1997): Agrártermelés és nemzetgazdaság. Glatz Ferenc szerk. Magyar Agrárgazdaság jelene és kilátásai. Budapest,1997 Magyar Tudományos kadémia. pp. 133-134.

Varga Tibor, szerk., Tunyoginé Nechay Veronika, szerk., Mizik Tamás, szerk. (2007): A mezögazdasági árképzés elméleti alapjai és hazai gyakorlata. Agrárgazdasági Tanulmányok. Agrárgazdasági Kutató Intézet, 2007.2. szám, Budapest, pp. 30-31.

Veress László, Dunka Béla (2003): Fejezetek a magyar állattenyésztés történetéből. Debreceni Egyetem Agrártudományi Centrum Mezőgazdaságtudományi Kara és a Mezőgazda Kiadó (Nemzeti Kulturális Alapprogram támogatta), pp. 94-105.

Vinkler Béláné (2013): Gondolatok a hazai mezögazdasági vállalkozások helyzetéről. Regionális Földrajzi Tanulmányok. Abonyiné Dr. Palotás Jolán 70. születésnapja tiszteletére. Egyesület Közép-Európai Kutatására. Szeged 2013.05.24. ISSN 2062-3712 ISBN: 978-963-89724-2-2. pp. 91-98.

Vinkler Béláné (2005): A kis-és középvállalkozások helyzete napjainkban. Dunaújvárosi Főiskola Közleményei XXVII/II. pp 639-642.

Agrárkutató Intézet Információs Rendszer. Sertésinformációs rendszer https://sertesinfo.aki.gov.hu/publikaciok/publikacio/a:661/Hasznos+internete s+oldalak 